\title{
CDISC SDTM Body Position Terminology
}

National Cancer Institute

\section{Source}

National Cancer Institute. CDISC SDTM Body Position Terminology. NCI Thesaurus.

Code C71148.

Terminology codelist used with Body Position within the Clinical Data Interchange Standards Consortium Study Data Tabulation Model. 